\title{
Unequal impact of age, percentage body fat, and serum testosterone concentrations on the somatotropic, IGF-I, and IGF-binding protein responses to a three-day intravenous growth hormone-releasing hormone pulsatile infusion in men
}

\author{
Ali Iranmanesh ${ }^{1}$, Steve South ${ }^{2}$, Ay Yin Liem ${ }^{3}$, David Clemmons ${ }^{4}$, Michael O Thorner ${ }^{5}$, Arthur Weltman ${ }^{5,6}$ and \\ Johannes D Veldhuis ${ }^{5}$ \\ ${ }^{1}$ Endocrine Section, Medical Service, Veterans Affairs Medical Center, Salem, Virginia 24153, USA, ${ }^{2}$ Gilford Medical Associates, Greensboro, North \\ Carolina 27403, USA, ${ }^{3}$ School of Medicine, University of Utrecht, The Netherlands, ${ }^{4}$ Department of Medicine, University of North Carolina School of \\ Medicine, Chapel Hill, North Carolina 27599, USA, ${ }^{5}$ Division of Endocrinology and Metabolism, Department of Medicine, University of Virginia \\ Health Sciences Center, Charlottesville, Virginia 22908, USA and ${ }^{6}$ Exercise Physiology Laboratory, General Clinical Research Center, University of \\ Virginia Health Sciences Center, Charlottesville, Virginia 22908, USA \\ (Correspondence should be addressed to J D Veldhuis, Division of Endocrinology, Department of Internal Medicine, Box 202, University of Virginia \\ Health Sciences Center, Charlottesville, Virginia 22908, USA)
}

\begin{abstract}
We here investigate the potential rescue of the relative hyposomatotropism of aging and obesity by 3-day pulsatile GHRH infusions (i.v. bolus $0.33 \mu \mathrm{g} / \mathrm{kg}$ every $90 \mathrm{~min}$ ) in 19 healthy men of varying ages (18 to 66 years) and body compositions (12 to 37\% total body fat). Baseline (control) and GHRHdriven pulsatile GH secretion (in randomly ordered sessions) were quantitated by deconvolution analysis of 24-h (10-min sampling) serum GH concentration profiles measured in an ultrasensitive (threshold $0.005 \mu \mathrm{g} / \mathrm{l}$ ) chemiluminescence assay. GHRH infusion significantly increased the mean (24h) serum GH concentration $(0.3 \pm 0.1$ basal vs $2.4 \pm 0.4 \mu \mathrm{g} / \mathrm{l}$ treatment; $P=0.0001)$, total daily pulsatile $\mathrm{GH}$ production rate $(21 \pm 9.5 \mathrm{vs} 97 \pm 17 \mu \mathrm{g} / \mathrm{l} /$ day; $P=0.01)$, GH secretory burst frequency ( $11 \pm 0.5$ vs $17 \pm 0.3$ events/day; $P=<0.01)$, and mass of $\mathrm{GH}$ released per burst $(1.1 \pm 0.4$ vs $5.9 \pm 1 \mu \mathrm{g} / \mathrm{l} ; P<0.01)$, as well as serum IGF-I $(261 \pm 33$ vs $436 \pm 37 \mu \mathrm{g} / \mathrm{l} ; P=0.005)$, insulin $(45 \pm 13$ vs $79 \pm 17 \mathrm{mU} / \mathrm{l} ; P=0.0002)$, and IGF binding protein (IGFBP)-3 (3320 \pm 107 vs $4320 \pm 114 \mu \mathrm{g} / \mathrm{l} ; P=0.001)$ concentrations, while decreasing IGFBP-1 levels $(16 \pm 1.2$ vs $14 \pm$ $0.09 \mu \mathrm{g} / \mathrm{l} ; P=0.02)$. Serum total testosterone and estradiol concentrations did not change. GHRH treatment also reduced the half-duration of GH secretory bursts, and increased the GH half-life. GHRH-stimulated 24-h serum GH concentrations and the mass of GH secreted per burst were correlated negatively with age $(R[$ value]: $P[$ value $]=-0.67: 0.002$ and $-0.58: 0.009$ respectively $)$, and percentage body fat $(R: P=-0.80: 0.0001$ and $-0.65: 0.005$ respectively), but positively with serum testosterone concentrations $(R: P=+0.55: 0.016$ and $+0.53: 0.019$ respectively). GHRHstimulated plasma IGF-I increments correlated negatively with age and body mass index, and positively with serum testosterone, but not with percentage body fat. Cosinor analysis disclosed persistent nyctohemeral rhythmicity of GH secretory burst mass (with significantly increased 24-h amplitude and mesor values) but unchanged acrophase during fixed pulsatile GHRH infusions, which suggests that both GHRH- and non-GHRH-dependent mechanisms can modulate the magnitude (but only non-GHRH mechanisms can modulate the timing) of somatotrope secretory activity differentially over a 24-h period.

In summary, diminished GHRH action and/or non-GHRH-dependent mechanisms (e.g. somatostatin excess, putative endogenous growth hormone-releasing peptide deficiency etc.) probably underlie the hyposomatotropism of aging, (relative) obesity, and/or hypoandrogenemia. Preserved or increased tissue IGF-I responses to GHRH-stimulated GH secretion (albeit absolutely reduced, suggesting GHRH insensitivity in obesity) may distinguish the pathophysiology of adiposity-associated hyposomatotropism from that of healthy aging.
\end{abstract}

European Journal of Endocrinology 139 59-71

\section{Introduction}

Increasing age and body fat singly and jointly suppress pulsatile growth hormone (GH) secretion (1-9). However, the pathophysiological disruption of $\mathrm{GH}$ secretion in these hyposomatotropic states has been difficult to quantitate, since $22-97 \%$ of daytime (awake, nonfasting) and fed serum $\mathrm{GH}$ concentrations fall 
below the limits of detectability of most RIA and IRMA techniques $(5,7,8,10)$. More recent ultrasensitive chemiluminescence assays and an ELISA for $\mathrm{GH}$ (sensitivities of approximately $0.001-0.005 \mu \mathrm{g} / \mathrm{l}$ ) can measure serum GH concentrations uniformly in normal and hyposomatotropic adults. Such assays document consistently small amounts of apparently basal (interpulse) $\mathrm{GH}$ release $(7,8,11,12)$, and suggest differential regulation of pulsatile versus basal GH secretion; e.g. testosterone is a positive, and obesity or age a negative, statistical determinant of GH secretory pulse mass, but not basal GH secretion (7); organic hypopituitarism is marked by preferential attenuation of $\mathrm{GH}$ secretory burst mass (11); and the total daily pulsatile $\mathrm{GH}$ secretion rate correlates positively with serum insulin-like growth factor (IGF)-I and IGF binding protein (IGFBP)-1 concentrations, whereas basal GH secretion correlates inversely with IGFBP-3 concentrations (7).

Despite the foregoing assay advances, the neuroendocrine mechanisms underlying the hyposomatotropism accompanying (relative) obesity, aging, and hypoandrogenemia are poorly understood. Among possible pathophysiologies are somatostatin excess, growth hormone-releasing hormone (GHRH) deficiency and/or other hypothalamo-pituitary disturbances. In testing for GHRH deficiency, somatotropic responses to single and repetitive GHRH stimuli have been inconsistent, namely blunted or normal in aging and/or obese humans $(10,13-16)$. In addition, whether GHRH infusion amplifies the basal versus pulsatile components of $\mathrm{GH}$ secretion in normal, obese, relatively hypoandrogenemic, and/or aging individuals is not known.

We hypothesized that an i.v. pulsatile GHRH stimulus administered experimentally for several days would obviate some of the limitations of earlier single-dose, twice-daily, or continuous subcutaneous GHRH treatments, and help affirm or refute an hypothesis of GHRH deficiency or insensitivity in aging, obesity, or (physiological) hypoandrogenemia. If GHRH deficiency were the sole factor pertinent to the hyposomatotropism of adiposity, aging, and/or relative hypoandrogenemia, we predicted that sustained pulsatile GHRH drive would reduce or eliminate the strongly negative correlations otherwise observed between GH secretory activity and one or more of these key variables $(7,8)$.

To test an hypothesis of isolated GHRH deficiency in aging and/or obesity, we investigated a diverse cohort of healthy men (ages 18-66 years, percentage total body fat $12-37 \%$, and serum total testosterone $220-710 \mathrm{ng} /$ dl) at baseline (saline) and on day 3 of a $72-\mathrm{h}$ pulsatile i.v. GHRH infusion in randomly ordered sessions. We assessed by regression analysis the impact of age, testosterone, and percentage body fat on exogenous GHRH-driven GH secretory measures, as well as on serum concentrations of IGF-I, IGFBP-3, IGFBP-1, and insulin.

\section{Materials and methods}

\section{Human subjects}

Nineteen healthy men were recruited over a range of ages (18-66 years), body mass indices $\left(18-39 \mathrm{~kg} / \mathrm{m}^{2}\right)$, and percentage total body fat $(12-37 \%$, as determined by underwater weighing). Baseline data have been reported earlier (7). After provision of written informed consent approved by the Human Investigation Committees of the University of Virginia and the Salem VA Medical Center, volunteers were admitted to the General Clinical Research Center the night prior to blood sampling. A detailed history and physical examination were performed. No subject had any acute or chronic weight change, known disease, medication or drug use, strenuous exercise within $24 \mathrm{~h}$, recent transmeridian travel, or disruption of sleep-wake patterns. Screening blood measurements of hematological, renal and hepatic function, and metabolic indices were normal.

Each volunteer was studied twice at an interval of four or more weeks, and the order of study randomly assigned to no drug (control) or $0.33 \mu \mathrm{g} / \mathrm{kg}$ GHRH(129) $\mathrm{NH}_{2}$ (Geref, Serono Laboratories, Randolph, MA, USA) diluted in bacteriostatic water for i.v. bolus (1 min) infusion every $90 \mathrm{~min}$ for $72 \mathrm{~h}$. A second i.v. catheter was placed in a contralateral forearm vein at $0600 \mathrm{~h}$ on the second day of the control admission and on the third day of GHRH treatment for blood sampling $(1.5 \mathrm{ml} /$ sample) at 10-min intervals for $24 \mathrm{~h}$. Subjects received isocaloric meals at 0830,1200 , and $1800 \mathrm{~h}$ clocktimes with no intervening snacks or caffeine-containing beverages. Volunteers were awake and allowed to ambulate in the study room with bathroom privileges until $2300 \mathrm{~h}$ clocktime. Although sleep was not monitored, lights were extinguished at $2300 \mathrm{~h}$.

Underwater weighing was used to calculate the percentage body fat, as described earlier (9). Body mass index (BMI) was computed as the subject's weight in kilograms divided by his height in meters squared.

\section{GH assay}

An ultrasensitive chemiluminescence assay (Nichols Laboratories, San Juan Capistrano, CA, USA) with robotic automation $(7,8)$ was used to assay $\mathrm{GH}$ in all 145 serum samples from any given subject together to eliminate interassay variability. Assay sensitivity (four standard deviations (s.D.) above the zero dose tube) was $0.005 \mu \mathrm{g} / \mathrm{l}$. No serum GH measurements fell below $0.005 \mu \mathrm{g} / \mathrm{l}$, and not more than $5 \%$ of the measurements were below $0.030 \mu \mathrm{g} / \mathrm{l}$. The within-assay coefficients of variation ranged from $4.5 \%$ to $13 \%$. Within-sample s.D. were recalculated in each series as a dose-dependent power function of the 145 sample GH concentrations (for deconvolution analysis see below). Serum concentrations of IGF-I, IGFBP-1, and IGFBP-3 were assayed by RIA in 24-h pools (17). 


\section{Deconvolution analysis}

A multiparameter deconvolution technique was applied to quantitate $\mathrm{GH}$ secretion from the 24-h serum GH concentration profiles $(5-8,18,19)$. Preliminary fitting used waveform-independent deconvolution (PULSE2) (20), assuming a nominal GH secretory burst halfduration of 14-18 min and GH half-life of 16-18 min, as measured earlier (18). Basal GH secretion (PULSE2) approximated the lowest $4-6 \%$ of all serum $\mathrm{GH}$ measurements in that individual. These estimates were then used by multiparameter deconvolution analysis (DECONV) to quantify: GH secretory burst frequency (number of pulses per $24 \mathrm{~h}$ ), amplitude (maximal rate of $\mathrm{GH}$ secretion within a pulse, $\mu \mathrm{g} / \mathrm{l} /$ min), mass (integral or mass, $\mu \mathrm{g} / \mathrm{l}$, of the calculated $\mathrm{GH}$ secretory pulse), half-duration (duration in min of a secretory episode at half its maximal amplitude), basal $\mathrm{GH}$ secretion rate $(\mu \mathrm{g} / \mathrm{l} / \mathrm{min}$, basal amount of hormone secreted per unit distribution volume per unit time), and $\mathrm{GH}$ half-life (min). The daily pulsatile $\mathrm{GH}$ production rate is the product of the mean $\mathrm{GH}$ secretory burst mass and frequency, and the daily basal GH secretion rate the product of the mean basal secretion rate $(\mu \mathrm{g} / \mathrm{l} / \mathrm{min})$ and the duration of sampling $(1440 \mathrm{~min})$. The percentage pulsatile GH release is the ratio (expressed as a percentage) of daily pulsatile $\mathrm{GH}$ release to the grand total of pulsatile plus basal GH secretion.

Twenty-four-hour variations in calculated GH secretory burst mass were evaluated by cosinor analysis (21).

\section{Statistical analysis}

Data are presented as the mean \pm s.E.M. $(n=19)$. Paired Student's $t$-testing (two-tailed) was used, and confirmed by Wilcoxon nonparametric testing, to appraise the within-subject effects of GHRH treatment. To evaluate age-, adiposity-, and sex-steroid hormone-dependent changes in $\mathrm{GH}$ secretory measures in response to GHRH infusions, univariate linear or exponential regression analyses were employed (7). When more than five regressions were carried out, a protected $P$ value of 0.01 or less was utilized.

\section{Results}

\section{Overall GH responses}

Pulsatile i.v. GHRH infusion stimulated GH release in all 19 subjects regardless of age and percentage body fat, as illustrated in Fig. 1. GHRH treatment increased the 24-h mean serum GH concentration (control vs GHRH) $(0.30 \pm 0.11$ vs $2.4 \pm 0.4 \mu \mathrm{g} / \mathrm{l} ; P=0.0001)$, and its integrated value $(427 \pm 153$ vs $3400 \pm 540 \mu \mathrm{g} / \mathrm{l} / \mathrm{min}$; $P=0.0001)$. Pulsatile GHRH injections also significantly altered the following paramaters: frequency of GH secretory bursts (control vs GHRH) $(11 \pm 0.5$ vs
$17 \pm 0.3 ; P<0.01)$, GH secretory burst half-duration $(24 \pm 2.4$ vs $4.4 \pm 0.72 \mathrm{~min} ; P<0.01)$, GH secretory burst amplitude $(0.05 \pm 0.01$ vs $2.1 \pm 0.5 \mu \mathrm{g} / \mathrm{l} / \mathrm{min}$; $P<0.01)$, GH secretory burst mass $(1.1 \pm 0.4$ vs $5.9 \pm 1.0 \mu \mathrm{g} / \mathrm{l} ; \quad P<0.01)$, total daily pulsatile $\mathrm{GH}$ secretory rate $(21 \pm 9.5$ vs $97 \pm 17 \mu \mathrm{g} / \mathrm{l} /$ day; $P<$ 0.01 ), and grand total (basal and pulsatile) daily $\mathrm{GH}$ production rate $(22 \pm 10$ vs $100 \pm 18 \mu \mathrm{g} / \mathrm{l} /$ day; $P<$ 0.01) (Fig. 2). GHRH augmented both pulsatile $(21 \pm 9.5 \mu \mathrm{g} / \mathrm{l} /$ day $(82 \pm 5 \%$ of total $)$ vs $97 \pm 17 \mu \mathrm{g} / \mathrm{l} /$ day $(96 \pm 1 \%$ of total $))$ and basal $(0.66 \pm 0.09$ vs $3.1 \pm$ $0.72 \mu \mathrm{g} / \mathrm{l} / \mathrm{min}$ ) GH secretion (Fig. 3). GHRH treatment also slightly, but consistently, prolonged GH half-life (16.9 \pm 0.9 vs $20.5 \pm 1.3 \mathrm{~min} ; P<0.01)$.

Pulsatile GHRH infusions augmented the serum (24-h pool) concentrations of IGF-I (control vs GHRH) $(261 \pm 33$ vs $436 \pm 37 \mu \mathrm{g} / \mathrm{l} ; \quad P<0.05)$, IGFBP-3 $(3320 \pm 107$ vs $4320 \pm 114 \mu \mathrm{g} / \mathrm{l} ; P<0.05)$, glucose $(5.2 \pm 0.37$ vs $6.1 \pm 0.56 \mathrm{mmol} / \mathrm{l} ; \quad P=0.002)$ and insulin $(45 \pm 13$ vs $79 \pm 17 \mathrm{IU} / \mathrm{l} ; P=0.0002)$, and reduced the mean serum concentration of IGFBP-1 $(16 \pm 1.2$ vs $14 \pm 0.9 \mu \mathrm{g} / \mathrm{l} ; P=0.02)$ (Fig. 4$)$. On the other hand, GHRH injections did not alter the (24-h

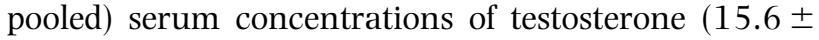
1.4 vs $16.2 \pm 1.4 \mathrm{nmol} / \mathrm{l} ; P>0.05$ ) or estradiol ( $144 \pm$ 10 vs $133 \pm 10 \mathrm{pmol} / \mathrm{l} ; P>0.05)$.

\section{Effect(s) of age, percentage body fat, or serum testosterone concentration on responses to GHRH}

During pulsatile infusions of GHRH, mean (24-h) serum concentrations of GH remained negatively correlated to age and relative adiposity, defined either by BMI or percentage body fat (Table 1 and Fig. 5). Age and body fat were correlated negatively to both the absolute and incremental (difference between post-GHRH and basal) mean 24-h serum GH concentration, GH production rate, and mass of GH secreted per burst. In contrast, the regression of serum testosterone on GHRH-stimulated (absolute) serum GH concentration did not attain significance. However, serum testosterone correlated strongly and positively with GHRH-stimulated absolute or incremental (total) GH production rate or incremental serum GH concentration (Table 1 and Fig. 5).

Figure 6 presents the individually observed $(n=19$ men) basal, incremental, and GHRH-stimulated values of (mean 24-h) GH secretory burst mass, given as a function of age (top panel), serum total testosterone concentration (second panel), BMI (third panel), and percentage body fat (bottom panel).

Figure 7 depicts the individual basal, incremental, and GHRH-stimulated serum IGF-I concentrations in relation to age, percentage body fat, BMI and serum testosterone concentrations. Correlation coefficients for corresponding regressions are given in Table 1. Serum IGF-I concentrations (incremental and absolute) were 


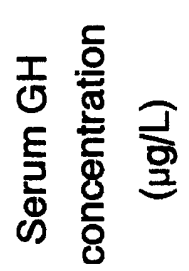

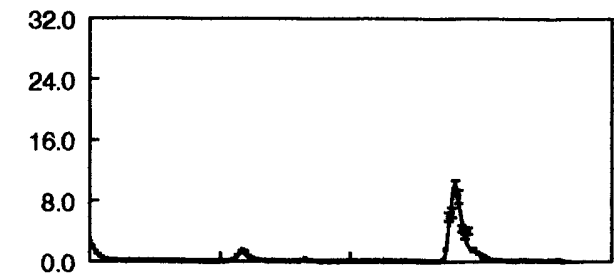

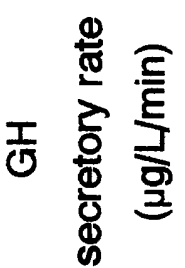

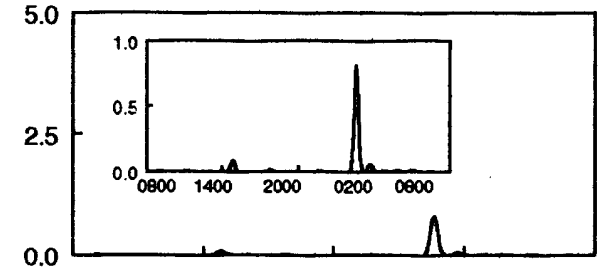

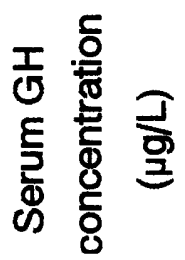

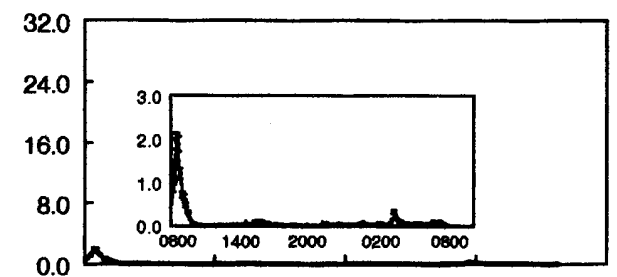

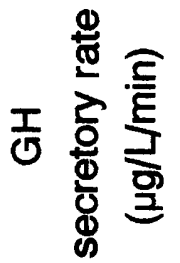
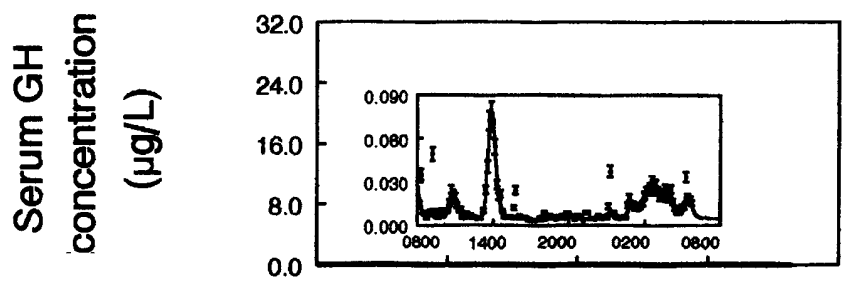

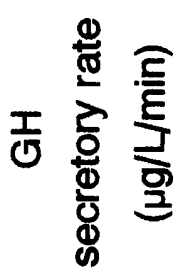
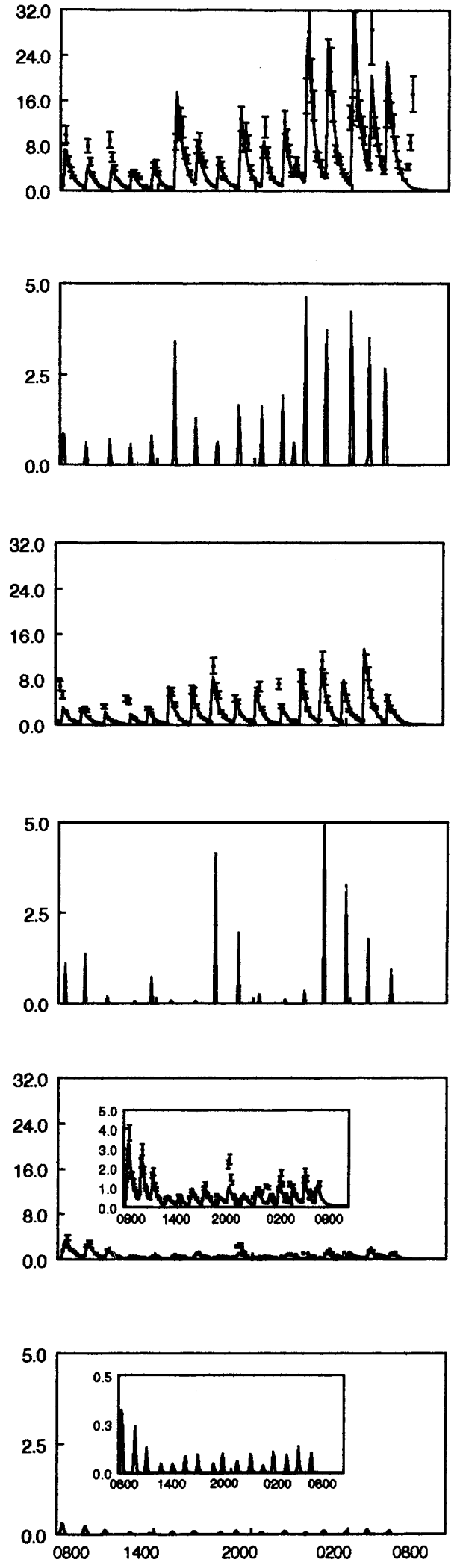

Clocktime 

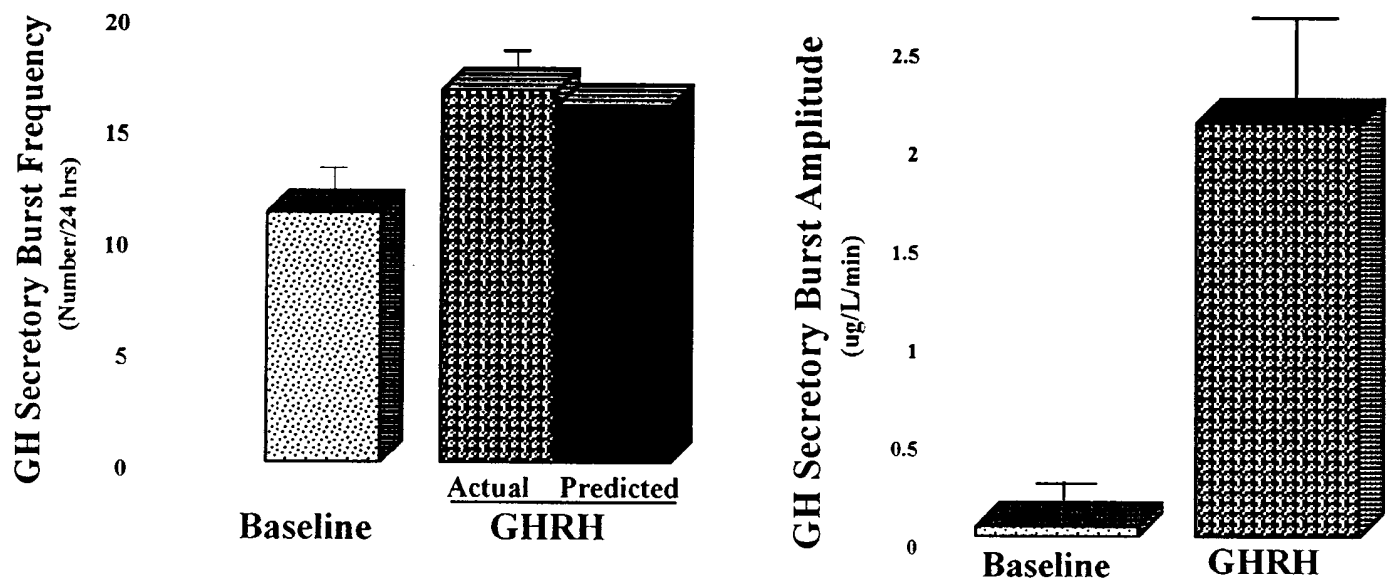
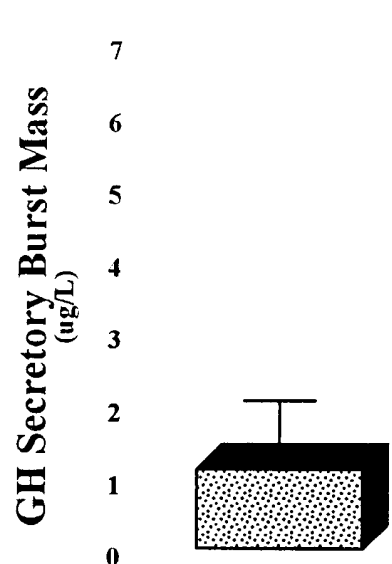

Baseline
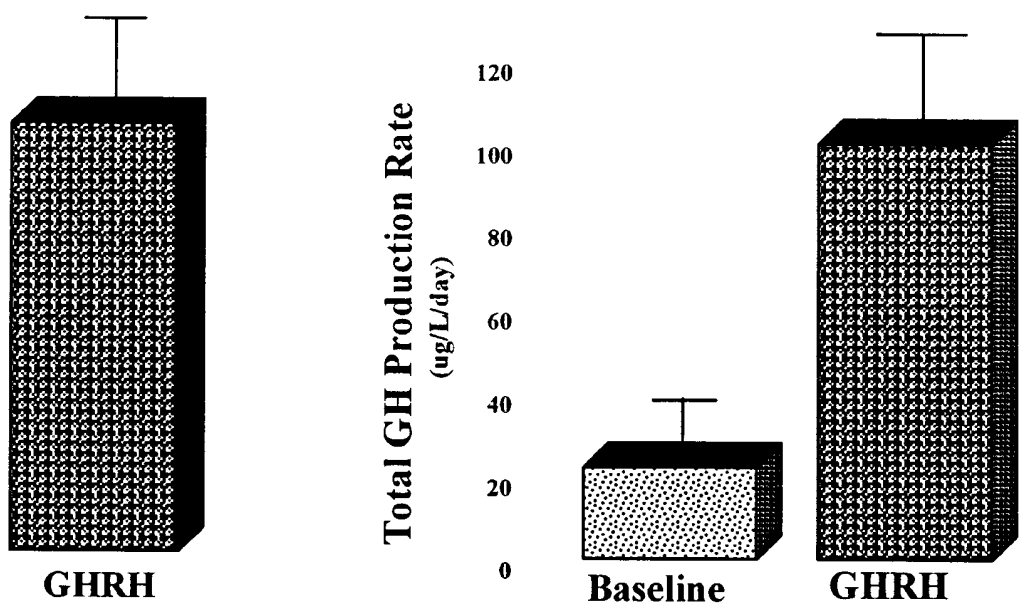

Figure 2 Summary of specific GH secretory parameters and the total daily GH production rate basally (control) and in response to i.v. pulsatile GHRH $(0.33 \mu \mathrm{g} / \mathrm{kg})$ administration over $72 \mathrm{~h}$ in 19 men of varying ages and body compositions. Data are means \pm S.E.M. $P<0.01$ for all paired comparisons shown.

statistically independent of percentage body fat during GHRH administration, whereas GHRH-stimulated incremental (but not absolute) serum IGF-I levels correlated negatively with age and BMI, and positively with serum testosterone concentrations $(P=0.051$ for $R=$ $+0.454)$. Estradiol levels did not correlate with any of the foregoing $\mathrm{GH}$-axis responses to GHRH.

Figure 8 shows the relationships of the ratios of serum IGF-I to GH pulse mass (during placebo or GHRH treatment) to percentage body fat (top panel), testosterone (middle panel), and age (bottom panel). The basal (non-GHRH treatment) ratio of serum IGF-I to GH burst mass correlated, respectively, negatively $(R=$ $-0.623, P=0.006)$ and positively $(R=+0.724, P=$ $0.007)$ with testosterone and age. On the other hand, percentage body fat correlated positively with serum IGF-I/GH burst mass during GHRH treatment $(R=+0.784, P=0.0002)$.

Figure 1 Illustration of the 24-h profiles of serum GH concentrations and calculated GH secretory rates before (left column) and during the last day of 3 days of pulsatile i.v. GHRH administration (right column) at a dose of $0.33 \mu \mathrm{g} / \mathrm{kg}$ every $90 \mathrm{~min}$ in three men of different ages and body compositions. Subpanels are paired vertically and horizontally. The top subpanels in each vertical pair represent serum $\mathrm{GH}$ concentrations in each man measured by chemiluminescence assay in blood samples collected at 10-min intervals over a period of $24 \mathrm{~h}$. The continuous curves through the observed serum GH levels are predicted by deconvolution analysis (see Materials and methods). The matching lower subpanels in each man depict the corresponding deconvolution-calculated GH secretory events and any basal GH secretion as a function of time. Note different $y$-axis scales to accommodate the wide range of serum GH concentrations attained. Insets show expanded axis views. Ages were (top-to-bottom pairs) 18, 31, and 57 years, and percentages of total body fat were 12, 31 , and 37 in the 3 men whose GH data are shown here. 

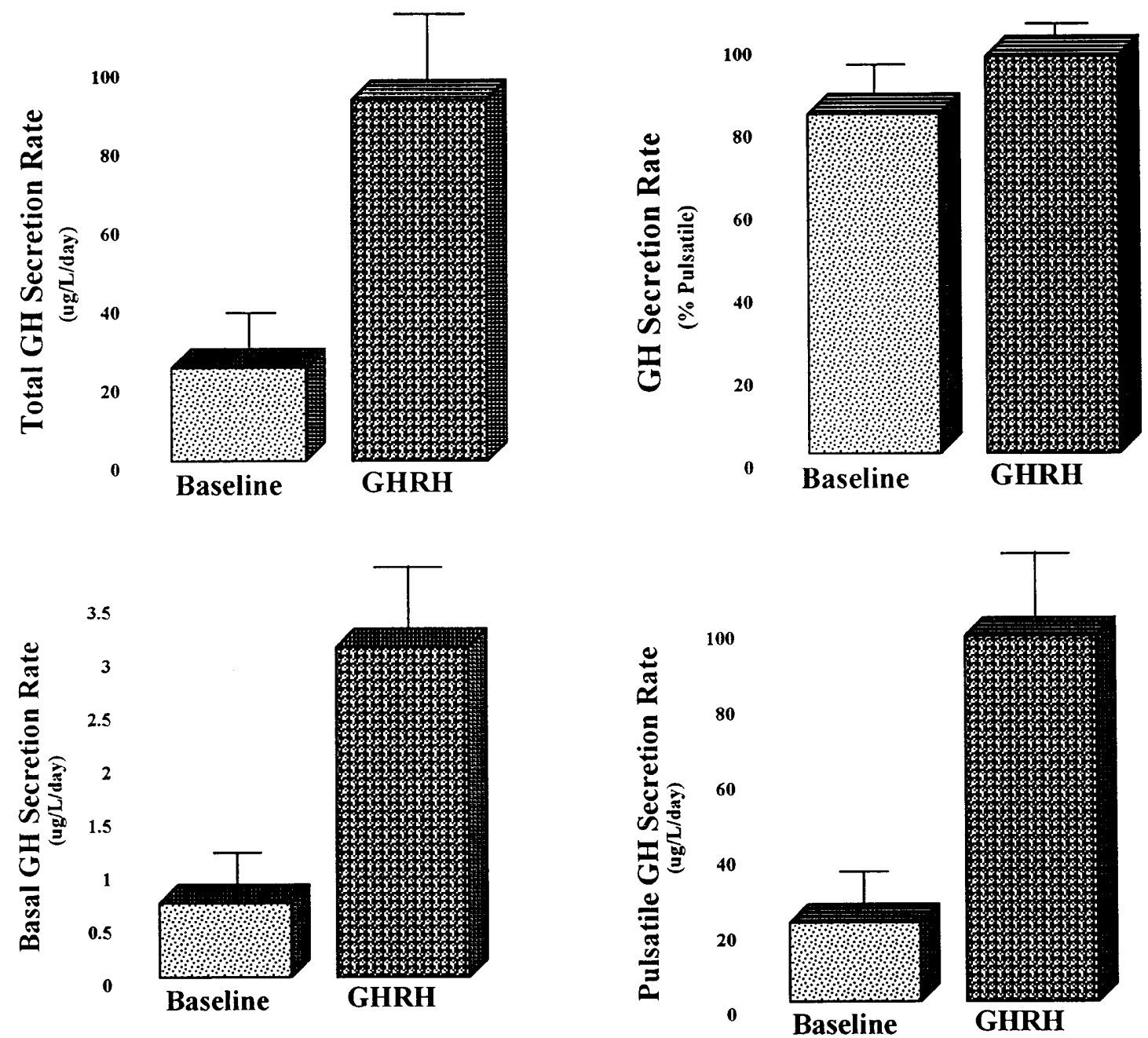

Figure 3 Total daily GH secretory rates with the respective contributions of pulsatile and basal (non pulsatile) GH secretory components before and during the last $24 \mathrm{~h}$ of 72 -h i.v. administration of GHRH pulses at 90 -min intervals in 19 men of differing ages and body compositions. Data are means \pm S.E.M. $P<0.01$ for all paired comparisons shown.

\section{GH nyctohemeral rhythmicity}

As shown in Fig. 9, cosinor analysis revealed diurnal (24-h) rhythmicity of GH secretory burst mass both basally and during pulsatile GHRH infusions. There were no significant differences in the mean $(95 \%$ confidence interval) times of the circadian acrophases, namely, 1031 (841-1236) min vs 1112 (1009-1217) min after $0800 \mathrm{~h}(P=$ not significant $)$ for the basal and the GHRH-infusion sessions respectively. However, GHRH infusions significantly increased the amplitude $(1.8(0.31-3.3)$ vs $4.7(2.6-6.8) \mu \mathrm{g} / \mathrm{l} ; P=<0.05)$ and mesor $(1.8(0.78-2.9)$ vs $6.2(4.7-7.9) \mu \mathrm{g} / \mathrm{l} ; P=<0.01)$ of the 24-h variation in GH secretory burst mass.

\section{Discussion}

To test a hypothesis of isolated GHRH deficiency or GHRH resistance in aging and/or obesity, we applied an experimental paradigm of unvarying i.v. pulsatile GHRH infusions over $72 \mathrm{~h}$ in a diverse cohort of healthy men $(n=19)$ of varying ages (span, 18-66 years) and degrees of adiposity (range of percentage total body fat, $12-37 \%)$. Three days of an experimentally fixed GHRH 'clamp' stimulated both pulsatile and interpeak basal GH secretion, and elevated serum IGF-I, IGFBP-3, and insulin concentrations, while lowering IGFBP-1 levels in each study subject. This is consistent with but not proof of (partial) GHRH deficiency. However, despite uninterrupted i.v. infusions of GHRH every $90 \mathrm{~min}$ for $72 \mathrm{~h}$, mean 24-h serum GH concentrations remained strongly negatively determined statistically by age, BMI, and percentage body fat, which is consistent with, among other considerations, relative GHRH insensitivity. These major inverse relationships applied also to the daily pulsatile GH secretory rate, and the mass of GH secreted per burst, and were evident from 

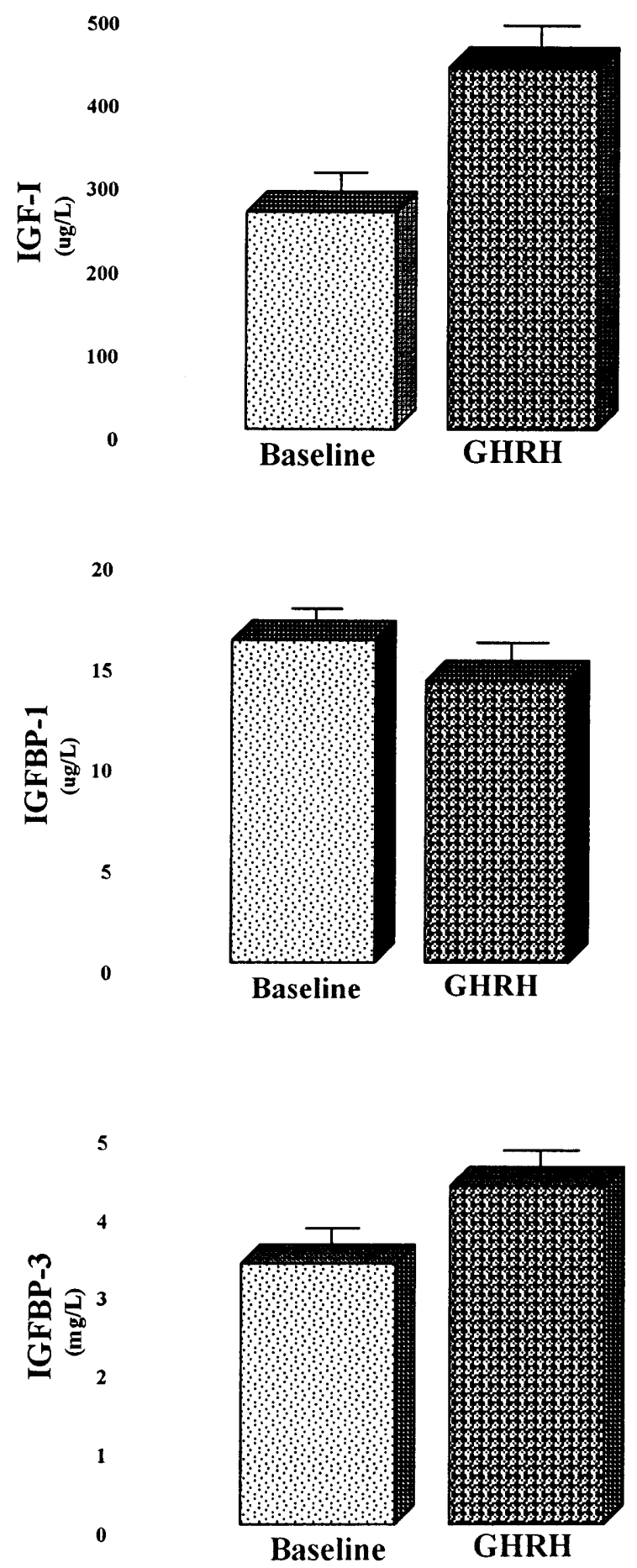

Figure 4 Effect of 72-h pulsatile i.v. administration of GHRH every 90 min on serum concentrations of IGF-I and two IGF-I binding proteins (IGFBP-1 and IGFBP-3) in 19 men of variable ages and body compositions. Data are means \pm S.E.M. $P<0.05$ for all paired comparisons shown, except $P=0.02$ for the IGFBP-1 comparison.

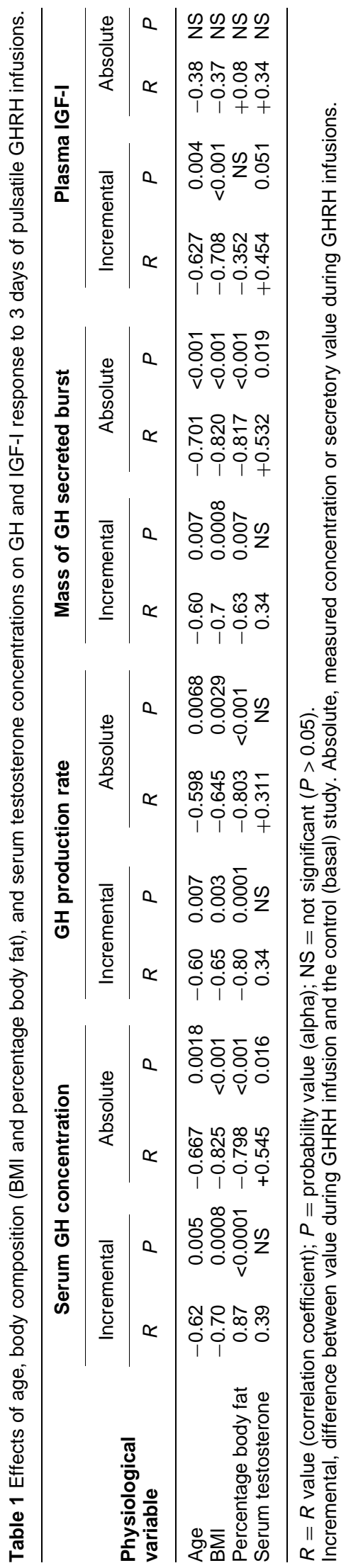



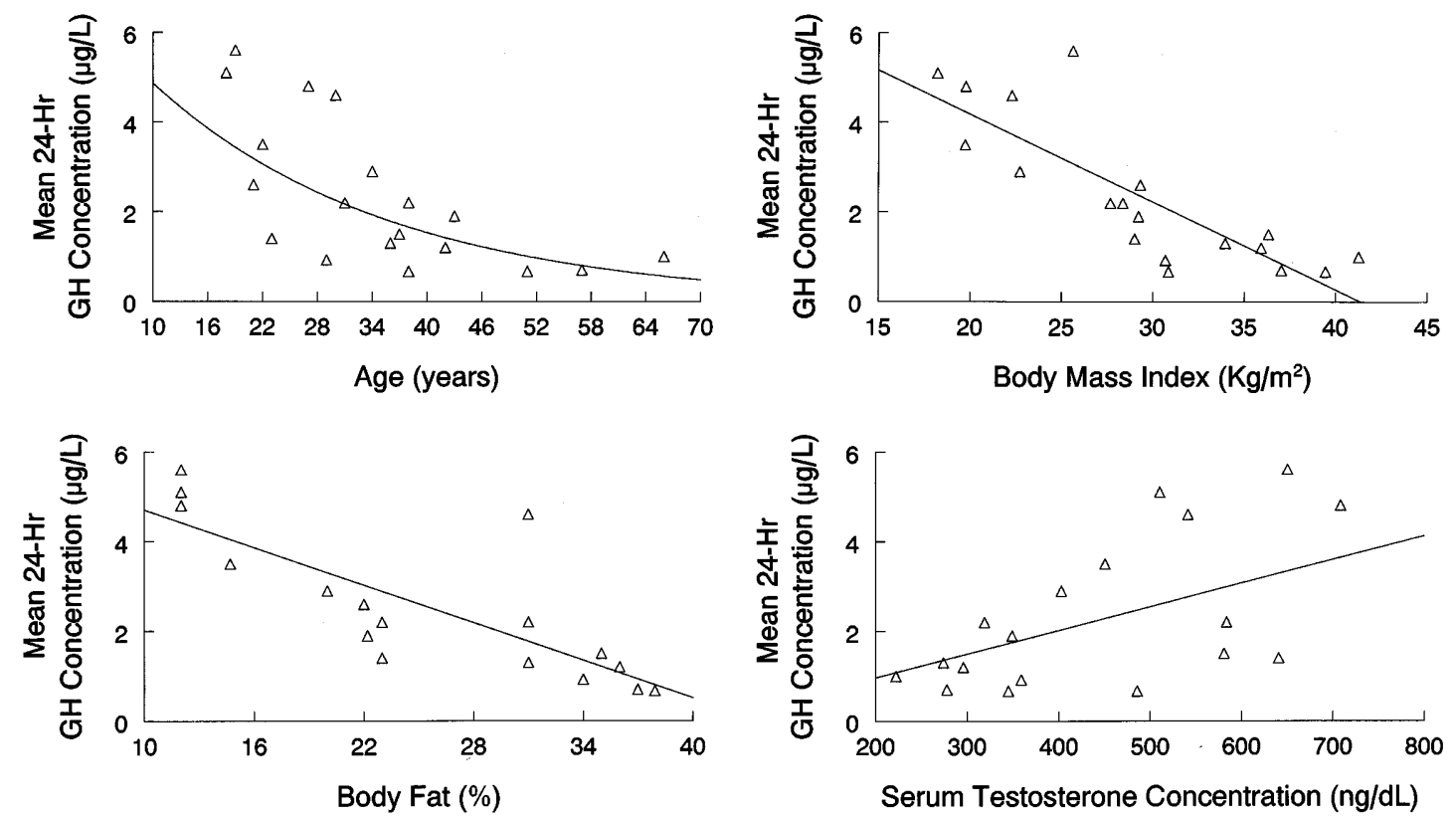

Figure 5 Linear regressions of age, body mass index, percentage body fat, and total serum testosterone concentrations on the mean 24-h serum GH concentrations during pulsatile i.v. infusion of GHRH over $72 \mathrm{~h}$ in 19 men. All regressions are $P<0.02$. Exact statistical values for the individual correlations are given in Table 1.

the perspectives of both absolute and incremental GH secretory responses. Thus, somatotrope $(\mathrm{GH})$ responsiveness to exogenous GHRH drive is clearly attenuated by increasing age and relative adiposity, suggesting relative resistance to GHRH, lack of GH co-secretagogues, and/or excessive GHRH antagonism (e.g. due to heightened somatostatin tone).

Both greater age and percentage body fat are associated with markedly reduced spontaneous pulsatile $\mathrm{GH}$ release (7). Given such baseline relative hyposomatotropism, the consistent amplification of 24-h GH secretion in all 19 men during pulsatile GHRH stimulation indicates significant (but incomplete) preservation of somatotropic secretory capability in older relatively hypoandrogenemic, and/or more obese individuals. Earlier studies have recorded attenuated GH secretion following a single GHRH challenge in obesity and aging $(10,15,16)$, albeit not always $(10,13)$. In a study of 50 men ranging in age from 21 to 86 years and with BMIs of 20 to $29 \mathrm{~kg} / \mathrm{m}^{2}$, Pavlou et al. discerned no impact of age on peak $\mathrm{GH}$ response following a single morning i.v. injection of GHRH $(1 \mu \mathrm{g} / \mathrm{kg})$, in contrast to a markedly negative effect of BMI (13). Corpas et al. observed similar peak serum GH concentrations after bolus administration of GHRH in a study of 9 young (22-33 years) versus 10 older (60-78 years) men (BMI: $\left.22-29 \mathrm{~kg} / \mathrm{m}^{2}\right)(10)$.

To avoid the well known moment-to-moment variability in the GH secretory response to a single stimulus of GHRH, we here used 72-h pulsatile infusions of GHRH, and 24-h blood sampling. We then evaluated by linear regression analysis any impact of age, BMI, or percentage body fat, as well as serum testosterone concentrations, on absolute (and incremental) 24-h GH secretory responses to GHRH. Even under unvarying GHRH drive, increased age and adiposity correlated negatively, and testosterone positively, with daily $\mathrm{GH}$ secretory activity. Thus, partially GHRH-independent or GHRH-resistant hyposomatotropism exists in aging and obesity. Conversely, testosterone appears to enhance pituitary GHRH actions. Various GHRH-independent or GHRH-resistant pathophysiological mechanisms are possible, and might include: (i) imperfect stimulation of pituitary cells by 3 days of pulsatile GHRH infusion alone, due to the choice of infusion dose or schedule; (ii) partial somatotrope-cell failure; (iii) increased hypothalamic somatostatin secretion and/or action; and/or (iv) accentuated GH or IGF-I feedback inhibition of the GH axis. The last mentioned is unlikely, at least in aging, since older subjects if anything are less sensitive to IGF-I's inhibition of GH secretion (22). Since older and obese humans can respond with significantly augmented pulsatile GH secretion and serum IGF-I concentrations to treatment with oral nonpeptidyl analogs of growth hormone-releasing peptide (GHRP) (23), an additional relevant hypothesis in aging and/or obesity is deficiency of a putative endogenous $\mathrm{GH}$ co-secretagogue, such as a GHRP-like agonist, whose identify is not yet established.

Results of the present 'GHRH clamp' argue against the $a$ priori hypothesis of an isolated GHRH deficiency in aging and obesity. However, an interpretation of a partial 
or non-exclusive diminution in (endogenous) GHRH action is consistent with reported near-normalization of blunted GH secretion in older men administered GHRH intermittently or continuously over 12 to 14 days (10). On the other hand, GH secretion failed to rise in obese or older subjects treated once daily with GHRH for 15 days
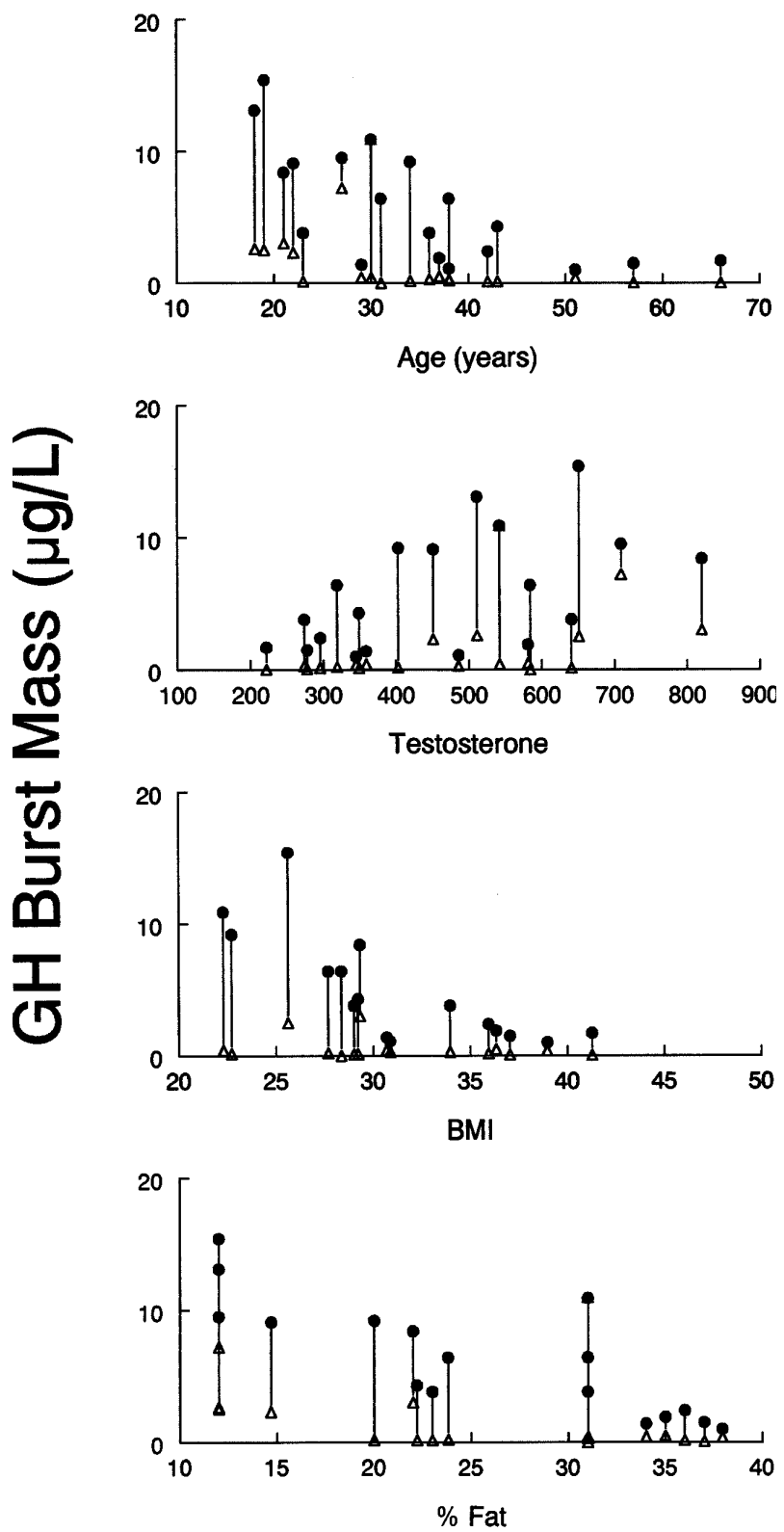

Figure $6 \mathrm{GH}$ secretory burst mass basally (placebo, control, $(\triangle)$ ) and in $\mathrm{GHRH}$-treated ( $)$ volunteers in relation to age, serum total testosterone concentrations, BMI, and percentage body fat in 19 men. GHRH $(0.33 \mu \mathrm{g} / \mathrm{kg})$ was administered i.v. every 90 min for 3 days. Vertical lines connect control and GHRH treatment sessions in each individual. (To convert serum testosterone concentrations in $\mathrm{ng} / \mathrm{dl}$ to $\mathrm{nmol} / \mathrm{l}$ multiply by 0.035 .)
$(24,25)$. Once daily GHRH treatment for 6 weeks also did not normalize serum IGF-I or IGFBP-3 concentrations in older men (26). Conversely, in obese subjects, GH secretion rose following both acute (single dose) and prolonged (repetitive doses over a 14-day period) GHRH administration, especially when combined with dietary restriction or fasting (16), weight loss (27), arginine (28), pyridostigmine (29), or GHRP-6 (30). Importantly, the foregoing treatments are believed to withdraw somatostatin (31), thus favoring our inference of at least dual defects in obesity. Analogously, in aging, GH secretion can be amplified many fold if GHRH is infused in combination with putatively somatostatin-antagonizing agents, e.g. L-arginine and/or the GH-releasing peptide, hexarelin $(25,32,33)$.

Although we cannot prove that a fully reconstituting GHRH stimulus is achieved by the present 72-h i.v. peptide infusions every $90 \mathrm{~min}$, this paradigm elicits near-physiological ultradian and nyctohemeral GH pulsatility (34). Assuming, furthermore, that preserved maximal somatotrope secretory capacity is preserved in obese and older individuals ((10), and above), the persisting negative regressions of $\mathrm{GH}$ secretory output on age and obesity during GHRH infusions suggests GHRH receptor insufficiency, relative lack of GH co-secretagogues, and/or excessive somatostatin release. Our data do not distinguish among these considerations. While studies in the rat or dog are not necessarily definitive to the human, experimental evidence in these species points to both decreased GHRH and increased somatostatinergic activity in older animals (e.g. references 35-37). A recent clinical paradigm of rebound $\mathrm{GH}$ secretion after somatostatin withdrawal also points to (partial) GHRH deficiency in aging (38).

Exogenous GHRH-stimulated GH pulsatility continued to follow a well defined 24-h rhythmicity, which is akin to the preserved nyctohemeral rhythmicity of serum GH concentrations reported recently in young men (39). Such diurnal variations during an unchanging GHRH stimulus suggest to us (but do not prove) concomitant 24-h non-uniformity in the release of somatostatin and/or co-secretagogues of GH. These considerations would also explain ongoing pulsatile $\mathrm{GH}$ release during continuous GHRH infusions (40). Since the amplitude and mesor (but not the acrophase) of the 24-h rhythm in GH secretory burst mass increased (by 2.5- and 3.5-fold respectively) during GHRH infusion, we infer that the magnitude but not the timing of daynight GH rhythmicity is modulated by GHRH. Timing appears to be GHRH independent. Thus, whether somatostatin and/or various $\mathrm{GH}$ co-secretagogues control the timing of 24-h GH rhythms remains plausible but unknown.

Unexpectedly, repeated pulsatile injections of GHRH evoked GH secretory bursts of abbreviated duration. In young men, exercise above the lactate threshold also induces short GH secretory pulses (41). We speculate 

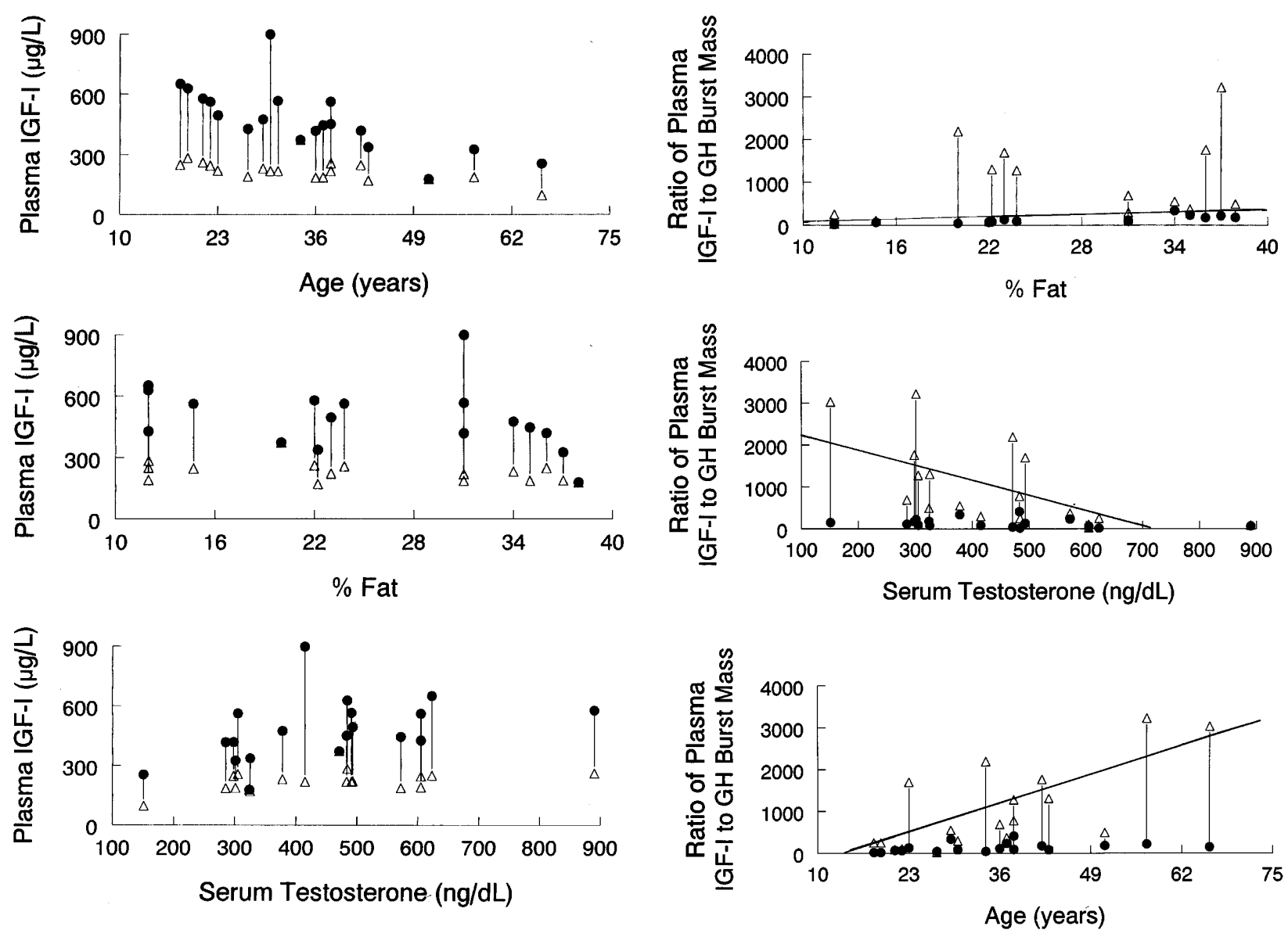

Figure 7 Serum IGF-I concentrations before (basal, placebo, $(\Delta)$ ) and during $(\bullet)$ pulsatile i.v. GHRH treatment for 3 days as a function of age, percentage body fat, and serum total testosterone concentrations in 19 men. Study sessions were randomly ordered, and are shown with a connecting vertical line. (To convert testosterone values in $\mathrm{ng} / \mathrm{dl}$ to $\mathrm{nmol} / \mathrm{l}$ multiply by 0.035 .)

that in these two settings either somatotrope cells release pre-stored GH immediately and briefly, and/or that hypothalamic somatostatin secretion is stimulated by GHRH, GH, or IGF-I auto-feedback, which thereby terminates GH release rapidly (31).

We found a small but reproducible increase in the calculated GH half-life during GHRH infusions. This most likely reflects the inverse relationship between the metabolic clearance rate of $\mathrm{GH}$ and circulating $\mathrm{GH}$ concentrations (42). Alternatively, an increase in serum GH-binding protein levels (not measured here) during GHRH infusions could in principle prolong GH half-life (43).

An additional novel observation is that pulsatile GHRH infusions augment interpulse basal GH secretion. Although the origin of basal (non pulsatile) $\mathrm{GH}$ secretion is not known, we speculate that each pulse of GHRH evokes an immediate release of pre-stored $\mathrm{GH}$ (detected as a peak), followed by delayed augmentation of GH stores and interpulse (basal) GH secretion. Other

Figure 8 Impact of percentage total body fat (top panel), serum testosterone concentration (middle panel), and age (bottom panel) on the ratio of serum IGF-I to GH secretory burst mass. Data are basal (control, $(\triangle)$ ) and the third day of pulsatile i.v. GHRH stimulation ( $)$ for $n=19$ men (see Materials and methods). Significant linear regressions are depicted by the continuous lines, for which the individual correlation coefficients and $P$ values are given in the Results section. (To convert testosterone levels in $\mathrm{ng} / \mathrm{dl}$ to $\mathrm{nmol} / \mathrm{I}$ multiply by 0.035 .)

considerations include basal GH secretion that is 'constitutive', partially GHRH dependent, and/or conditional on the overall GH production rate. Although pulsatile GHRH stimulation increased (absolute) basal $\mathrm{GH}$ secretion rates, it preferentially amplified the pulsatile component of total GH release. Thus, expressed as a fraction of total 24-h GH secretion, pulsatile $\mathrm{GH}$ secretion rose significantly during GHRH treatment, namely from $82 \%$ to $96 \%$. This response is like that observed in puberty and after sex steroid treatment, both of which magnify GH pulse mass $(44,45)$, thus suggesting that accentuated GHRH drive underlies pubertal activation of the $\mathrm{GH}$ axis. In addition, the disorderliness (approximate entropy) of GH release rose in the present study in all 19 men receiving GHRH infusions, consistent with similar changes in puberty $(31,46)$. 


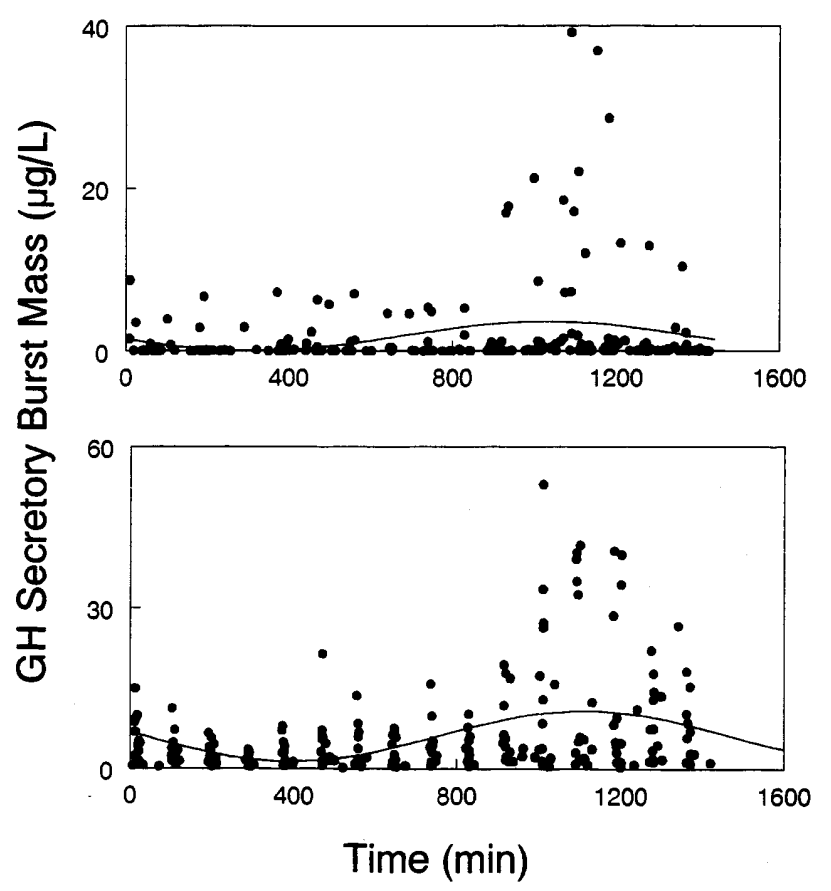

Figure 9 Nyctohemeral rhythmicity of deconvolution-calculated GH secretory burst mass in 19 men basally (upper panel, control) and on the third day of pulsatile i.v. GHRH (lower panel) infusions at 90min intervals for a period of $72 \mathrm{~h}$. The cosinor fits of the data assume 24-h periodicity. GHRH treatment significantly increased the mesor (mean) and amplitude of the 24-h rhythmicity in GH secretory burst mass, but did not alter the acrophase (timing of maximal value) (see Results).

GHRH-stimulated GH release was biologically active, given significant concomitant rises in serum glucose, insulin, IGF-I and IGFBP-3, with a reciprocal fall in IGFBP-1 concentrations. Age and BMI, but not percentage body fat, correlated negatively, and testosterone positively, with incremental serum IGF-I responses to GHRH infusion. The basis for the foregoing distinction between BMI and percentage body fat could reflect the relevance of topographic distribution of fat stores (e.g. visceral versus subcutaneous fat depots) to pituitary responses to GHRH infusions and/or tissue IGF-I responses to $\mathrm{GH}$ (47). Indeed, we observed in obesity that GHRH infusions augment serum IGF-I concentrations even in the face of attenuated pituitary $\mathrm{GH}$ secretion, suggesting normal or enhanced tissue IGF-I responses to $\mathrm{GH}$. This hypothesis would coincide with: (a) increased ultrafiltratable (free) IGF-I concentrations in obesity; relatively high IGF-I levels may in turn contribute by way of feedback to the evident hyposomatotropinemia of obesity (48), and (b) an increasing ratio of serum IGF to GH secretory burst mass in more obese men during GHRH stimulation (present data). Conversely, the falling ratio of serum IGF-I/GH secretory burst mass with higher serum testosterone concentrations in the untreated (basal) state suggests partial hepatic resistance to $\mathrm{GH}$ action due to testosterone, as inferred during (oral) estrogen treatment $(23,31)$. Lastly, the positive correlation of the ratio of serum IGF-I to $\mathrm{GH}$ burst mass with age in the basal (non GHRHtreated) state indicates apparently enhanced (hepatic) tissue IGF-I responsiveness to low basal (unstimulated) $\mathrm{GH}$ levels in aging. When exogenous GHRH is administered, however, the serum IGF-I/GH burst mass ratio no longer bears any relationship to age, which allows the hypothesis that experimentally increased pulsatile $\mathrm{GH}$ secretion augments IGF-I production similarly in older and young individuals. Such observations suggest that the impact of age on tissue IGF-I generation depends in part on GH concentration, i.e. at low serum GH concentrations, tissue IGF-I release is enhanced by increasing age, whereas at higher $\mathrm{GH}$ concentrations, tissue IGF-I responses are age independent. In contrast, higher serum GH concentrations (e.g. driven here by exogenous GHRH infusions) unmask an enhancing effect of percentage total body fat on circulating total IGF-I levels. In vivo GH dose-response studies ultimately will be required to test this hypothesized notion of unequal tissue sensitivities to $\mathrm{GH}$ in obese versus aging men.

\section{Acknowledgements}

This work has been presented in part at the 1995 Clinical Research Meeting of AAP/ASCI/AFCR.

We are grateful to Liza D Lategano-Wertz and Patsy Craig for assistance in preparation of the manuscript, Paula P Azimi for the statistical and pulse analysis, data presentation, and artwork, Robert Abbott for assistance in the regression analysis, Brenda Grisso and Mary Faron for the GH chemiluminescence assays, Sandra Jackson and the nurses at the General Clinical Research Center for their expert clinical care, and Serono Laboratories for providing GHRH.

This work was supported in part by Veterans Affairs Merit Review Research Award (A I, J D V), NIH RCDA \#1K04HD00634 ( J D V), RO1 DK32632 (M O T), RO1 AG147991 and RO3 AG14873 (J D V), Baxter HealthCare Corp. (Round Lake, IL, USA) ( J D V), NIH General Clinical Research Center (RR0847), the National Science Foundation Center for Biological Timing ( J D V, $\mathrm{M} \mathrm{O}$ T), and the Academic Enhancement Fund of the University of Virginia.

\section{References}

1 Finkelstein J, Roffwarg H, Boyar P, Kream J \& Hellman L. Agerelated changes in the twenty-four hour spontaneous secretion of growth hormone in normal individuals. Journal of Clinical Endocrinology and Metabolism 197235 665-670.

2 Rudman D, Vintner MH, Rogers CM, Lubin MF, Fleming GH \& Raymond PB. Impaired growth hormone secretion in the adult population. Journal of Clinical Investigation 198167 1361-1369.

3 Zadik Z, Chalew SA, McCarter Jr RJ, Meistas M \& Kowarski AA. The influence of age on the 24-hour integrated concentration of growth hormone in normal individuals. Journal of Clinical Endocrinology and Metabolism 198560 513-516. 
4 Ho KY, Evans WS, Blizzard RM, Veldhuis JD, Merriam GR Samojlik E, Furlanetto R, Rogol AD, Kaiser DL \& Thorner MO. Effects of sex and age on the 24-hour profile of growth hormone secretion in man: importance of endogenous estradiol concentrations. Journal of Clinical Endocrinology and Metabolism 198764 51-58.

5 Veldhuis JD, Iranmanesh A, Ho KKY, Lizarralde G, Waters MJ \& Johnson ML. Dual defects in pulsatile growth hormone secretion and clearance subserve the hyposomatotropism of obesity in man. Journal of Clinical Endocrinology and Metabolism 199172 51-59.

6 Iranmanesh A, Lizarralde G \& Veldhuis JD. Age and relative adiposity are specific negative determinants of the frequency and amplitude of growth hormone (GH) secretory bursts and the halflife of endogenous $\mathrm{GH}$ in healthy men. Journal of Clinical Endocrinology and Metabolism 199173 1081-1088.

7 Veldhuis JD, Liem AY, South S, Weltman A, Weltman J, Clemmons DA, Abbott R, Mulligan T, Johnson ML, Pincus SM, Straume M \& Iranmanesh A. Differential impact of age, sex-steroid hormones, and obesity on basal versus pulsatile growth hormone secretion in men as assessed in an ultrasensitive chemiluminescence assay. Journal of Clinical Endocrinology and Metabolism 199580 32093222 .

8 Iranmanesh A, Grisso B \& Veldhuis JD. Low basal and persistent pulsatile growth hormone secretion are revealed in normal and hyposomatotropic men studied with a new ultrasensitive chemiluminescence assay. Journal of Clinical Endocrinology and Metabolism 199478 526-535.

9 Weltman A, Weltman JY, Hartman ML, Abbott RA, Rogol AD, Evans WS \& Veldhuis JD. Relationship between age, percentage body fat, fitness and 24 hour growth hormone release in healthy young adults: effects of gender. Journal of Clinical Endocrinology and Metabolism 199478 543-548.

10 Corpas E, Harman SM \& Blackman MR. Human growth hormone and human aging. Endocrine Reviews 199314 20-39.

11 Reutens AT, Veldhuis JD, Hoffman DM, Leung KC \& Ho KKY. A highly sensitive growth hormone (GH) ELISA uncovers increased contribution of a tonic mode of $\mathrm{GH}$ secretion in adults with organic GH deficiency. Journal of Clinical Endocrinology and Metabolism 199681 1591-1597.

12 Friend KE, Iranmanesh A \& Veldhuis JD. The orderliness of the GH release process and the mass of $\mathrm{GH}$ secreted per burst are highly conserved in individual men on successive days. Journal of Clinical Endocrinology and Metabolism 199681 3746-3753.

13 Pavlou EP, Harman SM, Merriam GR, Gelato MC \& Blackman MR. Responses of growth hormone $(\mathrm{GH})$ and somatomedin-C to $\mathrm{GH}-$ releasing hormone in healthy aging men. Journal of Clinical Endocrinology and Metabolism 198662 595-600.

14 Lang I, Schernthaner G, Pietschmann P, Kurt R, Stephenson JM \& Templ H. Effects of sex and age on growth hormone response to growth hormone-releasing hormone in healthy individuals Journal of Clinical Endocrinology and Metabolism 198765 535540 .

15 Williams T, Berelowitz M, Joffe SN, Thorner MO, Rivier J, Vale W \& Frohman LA. Impaired growth hormone responses to growth hormone-releasing factor in obesity. A pituitary defect reversed with weight reduction. New England Journal of Medicine 1984311 1403-1407.

16 Csizmadi I, Brazeau P \& Serri O. Effect of dietary restriction and repeated growth hormone-releasing factor injections on growth hormone response to growth hormone-releasing factor in obese subjects. Metabolism: Clinical and Experimental $1989381016-$ 1021.

17 Clemmons DR, Dehoff ML, Busby WH, Bayne ML \& Cascieri MA. Competition for binding to insulin-like growth factor (IGF) binding protein-2, $-3,-4$, and -5 by the IGFs and IGF analogs. Endocrinology $1992131890-895$.

18 Faria ACS, Veldhuis JD, Thorner MO \& Vance ML. Half-time of endogenous growth hormone $(\mathrm{GH})$ disappearance in normal man after stimulation of GH secretion by GH-releasing hormone and suppression with somatostatin. Journal of Clinical Endocrinology and Metabolism 198968 535-541.

19 Veldhuis JD, Carlson ML \& Johnson ML. The pituitary gland secretes in bursts: appraising the nature of glandular secretory impulses by simultaneous multiple-parameter deconvolution of plasma hormone concentrations. Proceedings of the National Academy of Sciences of the USA 198784 7686-7690.

20 Veldhuis JD \& Johnson ML. Specific methodological approaches to selected contemporary issues in deconvolution analysis of pulsatile neuroendocrine data. Methods in Neurosciences 199528 25-92.

21 Veldhuis JD, Iranmanesh A, Johnson ML \& Lizarralde G. Twentyfour hour rhythms in plasma concentrations of adenohypophyseal hormones are generated by distinct amplitude and/or frequency modulation of underlying pituitary secretory bursts. Journal of Clinical Endocrinology and Metabolism 199071 1616-1623.

22 Chapman IM, Hartman ML, Pezzoli SS, Harrell Jr FE, Hintz RL, Alberti KGMM \& Thorner MO. Effect of aging on the sensitivity of growth hormone secretion to insulin-like growth factor-I negative feedback. Journal of Clinical Endocrinology and Metabolism 199782 2996-3004.

23 Chapman IM, Bach MA, Cauter EV, Farmer M, Krupa D, Taylor AM, Schilling LM, Cole KY, Skiles EH, Pezzoli SS, Hartman ML, Veldhuis JD, Gormley GJ \& Thorner MO. Stimulation of the growth hormone $(\mathrm{GH})$-insulin-like growth factor-I axis by daily oral administration of a $\mathrm{GH}$ secretagogue (MK-0677) in healthy elderly subjects. Journal of Clinical Endocrinology and Metabolism $1996814249-4257$.

24 Ghigo E, Bellone J, Mazza E, Imperiale E, Procopio M, Valente F, Lala R, De Sanctis C \& Camanni F. Arginine potentiates the GHRH- but not the pyridostigmine-induced GH secretion in normal short children. Further evidence for a somatostatinsuppressing effect of arginine. Clinical Endocrinology 199032 763-766.

25 Ghigo E, Ceda GP, Valcavi R, Goffi S, Zini M, Mucci M, Valenti G, Muller EE \& Camanni F. Effect of 15-day treatment with growth hormone-releasing hormone alone or combined with different doses of arginine on the reduced somatotrope responsiveness to the neurohormone in normal aging. European Journal of Endocrinology $199513232-36$.

26 Vittone J, Blackman MR, Busby-Whitehead J, Tsiao C, Stewart KJ, Tobin J, Stevens T, Bellantoni MF, Rogers MA, Baumann G, Roth J, Harman SM \& Spencer RG. Effects of single nightly injections of growth hormone-releasing hormone (GHRH 1-29) in healthy elderly men. Metabolism: Clinical and Experimental 199746 89-96.

27 Tanaka K, Inoue S, Numata K, Okazaki H, Nakamura S \& Takamura Y. Very-low-calorie diet-induced weight reduction reverses impaired growth hormone secretion response to growth hormone-releasing hormone, arginine, and L-dopa in obesity. Metabolism: Clinical and Experimental 199039 892-896.

28 Ghigo E, Procopio M, Boffano GM, Arvat E, Valente F, Maccario M, Mazza E \& Camanni F. Arginine potentiates but does not restore the blunted growth hormone response to growth hormonereleasing hormone in obesity. Metabolism: Clinical and Experimental 19924 560-563.

29 Cordido F, Casanueva FF \& Dieguez C. Cholinergic receptor activation by pyridostigmine restores growth hormone $(\mathrm{GH})$ responsiveness to GH-releasing hormone administration in obese subjects: evidence for hypothalamic somatostatinergic participation in the blunted GH release of obesity. Journal of Clinical Endocrinology and Metabolism 198968 290-293.

30 Cordido F, Penalva A, Dieguez C \& Casanueva FF. Massive growth $(\mathrm{GH})$ discharge in obese subjects after the combined administration of GH-releasing hormone and GHRP-6: evidence for a marked somatotroph secretory capability in obesity. Journal of Clinical Endocrinology and Metabolism 199376 819823 .

31 Giustina A \& Veldhuis JD. Pathophysiological basis of the neuroregulation of the somatotropic $(\mathrm{GH})$ axis in experimental animals and the human. Endocrine Reviews 1998 (In Press). 
32 Ghigo E, Goffi S, Nicolosi M, Arvat E, Valente F, Mazza E, Ghico MC \& Camanni F. Growth hormone $(\mathrm{GH})$ responsiveness to combined administration of arginine and GH-releasing hormone does not vary with age in man. Journal of Clinical Endocrinology and Metabolism 199071 1481-1485.

33 Arvat E, Gianotti L, Grottoli S, Imbimbo BP, Lenaerts V, Deghenghi R, Camanni F \& Ghigo E. Arginine and growth hormone-releasing hormone restore the blunted growth hormone-releasing activity of hexarelin in elderly subjects. Journal of Clinical Endocrinology and Metabolism 199479 1440-1443.

34 Hartman ML, Faria ACS, Vance ML, Johnson ML, Thorner MO \& Veldhuis JD. Temporal structure of in vivo growth hormone secretory events in man. American Journal of Physiology 1991260 E101-E110.

35 De Gennaro V, Zoli M \& Cocchi D. Reduced growth hormone releasing factor (GHRH)-like immunoreactivity and GHRH gene expression in hypothalamus of aged rats. Peptides $198910705-$ 709.

36 Cella SG, Locaatelli V, Poratelli M, De Gennaro Colonna V, Imbimbo BB, Deghenghi R \& Muller EE. Hexarelin, a potent GHRP analogue: interactions with GHRH and clonidine in young and aged dogs. Peptides $19951681-86$.

37 Sonntag WE, Forman LJ \& Miki N. Effects of CNS active drugs and somatostatin antiserum on growth hormone release in young and old male rats. Neuroendocrinology 198133 73-78.

38 degli Uberti EC, Ambrosio MR, Cella SG, Margutti AR, Trasforini G, Rigamonti AE, Petrone E \& Muller EE. Defective hypothalamic growth hormone $(\mathrm{GH})$-releasing hormone activity may contribute to declining GH secretion with age in man. Journal of Clinical Endocrinology and Metabolism 199782 2885-2888.

39 Jaffe CA, Turgeon DK, Friberg RD, Watkins PB \& Barkan AL Nocturnal augmentation of growth hormone $(\mathrm{GH})$ secretion is preserved during repetitive bolus administration of GH-releasing hormone: potential involvement of endogenous somatostatin. Journal of Clinical Endocrinology and Metabolism 1995803321 3326

40 Vance ML, Kaiser DL, Evans WS, Furlanetto R, Vale W, Rivier J \& Thorner MO. Pulsatile growth hormone secretion in normal man during a continuous 24-hour infusion of human growth hormone releasing factor (1-40). Journal of Clinical Investigation 198575 1584-1590.

41 Thompson DL, Weltman JY, Rogol AD, Metzger D, Veldhuis JD \& Weltman A. Cholinergic and opioid involvement in release of growth hormone during exercise and recovery. Journal of Applied Physiology $199375870-878$.

42 Schaefer F, Baumann G, Faunt LM, Haffner D, Johnson ML, Mercado M, Ritz E, Mehls O \& Veldhuis JD. Multifactorial control of the elimination kinetics of unbound (free) GH in the human: regulation by age, adiposity, renal function, and steady-state concentrations of GH in plasma. Journal of Clinical Endocrinology and Metabolism 199681 22-31.

43 Veldhuis JD, Johnson ML, Faunt LM, Mercado M \& Baumann G. Influence of the high-affinity growth hormone (GH)-binding protein on plasma profiles of free and bound $\mathrm{GH}$ and on the apparent half-life of GH. Journal of Clinical Investigation 199391 629-641.

44 Fryburg DA, Weltman A, Jahn LA, Weltman JY, Samolijik E \& Veldhuis JD. Short-term modulation of the androgen milieu alters pulsatile but not exercise or GHRH-stimulated GH secretion in healthy men. Journal of Clinical Endocrinology and Metabolism 199782 3710-3719.

45 Martha Jr PM, Goorman KM, Blizzard RM, Rogol AD \& Veldhuis JD. Endogenous growth hormone secretion and clearance rates in normal boys as determined by deconvolution analysis: relationship to age, pubertal status and body mass. Journal of Clinical Endocrinology and Metabolism 199274 336-344.

46 Veldhuis JD, Metzger DL, Martha Jr PM, Mauras N, Kerrigan JR, Keenan B, Rogol AD \& Pincus SM. Estrogen and testosterone, but not a non-aromatizable androgen, direct network integration of the hypothalamo-somatotrope (growth hormone)-insulin-like growth factor-I axis in the human: evidence from pubertal pathophysiology and sex-steroid hormone replacement. Journal of Clinical Endocrinology and Metabolism 199782 3414-3420.

47 Vahl N, Jorgensen JOL, Skjaerback C, Veldhuis JD, Orskov H \& Christiansen J. Abdominal adiposity rather than age and sex predicts the mass and patterned regularity of growth hormone secretion in mid-life healthy adults. American Journal of Physiology 1997272 E1108-E1116.

48 Frystyk J, Vestbo E, Skjaerbaek C, Mogensen CE \& Orskov H. Free insulin-like growth factors in human obesity. Metabolism 199544 $37-44$.

Received 27 November 1997

Accepted 30 March 1998 